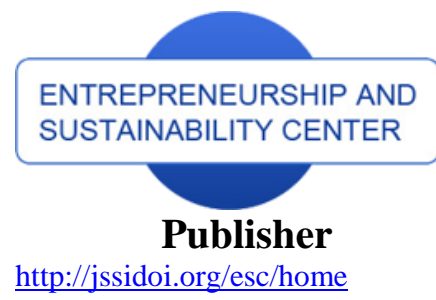

http://jssidoi.org/esc/home

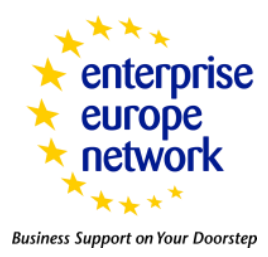

CASPA

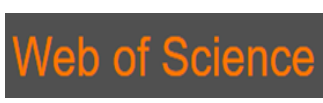

\section{Scopus}

1 Clarivate

Analytics

\title{
CONFIGURING THE SUSTAINABLE STRATEGY OF INTERNET CAFE IN YOGYAKARTA, INDONESIA, TO REMAIN POPULAR IN NOWADAYS*
}

\author{
Tangguh Okta Wibowo ${ }^{1}$, Wening Udasmoro ${ }^{2 * *}$, Ratna Noviani ${ }^{3}$ \\ 1,2,3 Universitas Gadjah Mada, Teknika Utara Street, Special Region of Yogyakarta, 55281, Indonesia
}

E-mails: ${ }^{1}$ tangguh.okta.w@mail.ugm.ac.id $;{ }^{2 * *}$ udasmoro@ugm.ac.id (Corresponding author); ${ }^{3}$ ratna.noviani@ugm.ac.id

Received 20 November 2019; accepted 27 July 2020; published 30 September 2020

\begin{abstract}
This paper deals with examining through analysis of the sustainable strategy of internet cafe to remain popular in nowadays. This research aims to examine the case study of the two internet cafe business chains in Yogyakarta, Indonesia. In particular, previous studies about internet cafe highlighted local and global consumption which relied on internet connection. Here this paper provides the discovery that consumers use internet connection only as a complement in the internet cafe. Besides, this paper considers that shifting an image for internet cafe is very important. This research applied the interdisciplinary approach. To conduct the research, the authors employed several methods: observations in the period of January to June 2018, in-depth qualitative interview with managers and consumers for supporting the analysis. The results of this paper indicate that internet cafes in Yogyakarta are successful in creating a strong local brand. They created line product categories with the concept of internet cafe regarding internet services as a place for hangout, co-working space, high-speed wifi connection, and access to almost all digital content provided free of charge. The role of global strategies is adopted to build a strong brand. It can be seen that the impact on customers who have a positive perception to gauge the benefits of internet cafes. The intersection between global strategy, standardization, and adaptation is an effective strategy to increase the sustainability development of internet cafe nowadays.
\end{abstract}

Keywords: Indonesia; internet cafe; sustainable strategy; warnet; Yogyakarta

Reference to this paper should be made as follows: Wibowo, T., W., Udasmoro, W., Noviani, R. 2020. Configuring the sustainable strategy of internet cafe in Yogyakarta, Indonesia, to remain popular in nowadays. Entrepreneurship and Sustainability Issues, 8(1), 11221132. http://doi.org/10.9770/jesi.2020.8.1(75)

JEL Classifications: L84, L86, Y40

Additional disciplines: Cultural Studies

\footnotetext{
* This paper is a part of the project 'Consumption Practices of Internet Cafe Users in Yogyakarta', which is funded by Indonesia Endowment Fund for Education (LPDP).
} 


\section{ENTREPRENEURSHIP AND SUSTAINABILITY ISSUES}

ISSN 2345-0282 (online) http://jssidoi.org/jesi/

2020 Volume 8 Number 1 (September)

http://doi.org/10.9770/jesi.2020.8.1(75)

\section{Introduction}

Internet cafe first appeared in 1985 in Santa Monica, California under the term "Electronic Cafe Network Project" as part of the Olympics festival Arts in Los Angeles (López-Bonilla et al, 2016). It was a non-profit project in supporting online collaboration and cultural research to develop into an international cultural research laboratory with more than 40 affiliates worldwide as Electronic Cafe International (Hanley 2002; López-Bonilla et al. 2016, p. 15). Only in 1990, internet cafe established in several cities of the world as a business that allowed people to rent a computer for internet access (Mancebo 2003; López-Bonilla et al. 2016). In 1994, a new phenomenon emerged with the presence of the first internet cafe, called Cyberia in London as a public space provided with computer and internet access, and a cafe (Liff \& Laegran 2003; Mutula 2003; Laegran 2009).

In the Indonesian context, since 1996, internet cafe was commercialized also as a place to access the internet, but we called it as warnet (local term in Bahasa Indonesia). Not less than 1996, in Indonesia, especially Yogyakarta, the internet had been open access and marked with banners (Hill \& Sen 1997). The internet at that time had transformed in a unique way in Indonesia through the structure of local power to access information (Lim 2003a) even with slow, unreliable, and inefficient internet speeds (Hill \& Sen 1997).

In 1995 until the end of 1999, warnet increasingly developed and became a high-tech home industry. This also affected the ownership. At first, the ownership of warnet was owned by individuals, then, individuals also owned a small warnet business chain in a city (Hill \& Sen 2007). Warnet with the jargon "making the internet widely available for everybody, especially students" and "everything is provided here" succeeded in attracting consumers, especially students, and providing all their needs (eg printing machines, CDs, and scans). This corporate-owned warnet had succeeded in forcing some individual-owned warnet to shut down (Lim 2003b).

However, it is a common opinion that the internet cafe business is becoming old-fashioned technology because of the increased use of mobile technology that is cheaper and globally accessible (LeBlanc \& Shrum 2017). This case is the same as the situation in Indonesia. The chairman of the Association of Indonesian Internet Cafes (AWARI) said that one of the causes of the decline in the popularity of warnet visitors because consumers were moving to use smartphones for internet access. On the other hand, internet subscription and the price of internet devices were increasingly cheaper. This affected the decline of warnet visitors in big cities (Karina 2011). However, that condition makes some warnets need to adapt if their business wants to thrive in the onslaught of mobile internet connections.

Therefore, to deal with the declining popularity of warnet, the internet business in Yogyakarta had changed from the form of warnet to internet cafe, including vast improvements in physical settings such as infrastructure, location, facilities, cafe presence, wifi coverage, and standardization branch. Borrowing terms from Chawla and Behl (2006), this type of internet cafe can be classified as the branded segment, which is a big player which creates a chain of internet cafes with certain standards and owned by corporations. This strategy was applied by the owners to thrive and to remain popular among consumers nowadays in Yogyakarta.

Nevertheless, the changing form of warnet did not automatically become an internet cafe, but there was also a contribution from global flow, such as design, cafe ambience, and infrastructure from internet cafe around the world. They (the owners) adopted the design for changes in the sector of infrastructure and cafes, but also in the sector of culture that was domesticated by the touch of local culture. By late 1997, the warnet changed using the concept of internet cafe and still thrived in 2019 by owning several branches of the internet cafe business and creating a strong brand in leading an internet business. In other words, there was a business extension, including the spread of several branches that contributed to determining regulation, price, facility, and to create an 


\section{ENTREPRENEURSHIP AND SUSTAINABILITY ISSUES}

ISSN 2345-0282 (online) http://jssidoi.org/jesi/

2020 Volume 8 Number 1 (September)

http://doi.org/10.9770/jesi.2020.8.1(75)

expansion of consumption patterns. To address the issue, this research discusses how the sustainable strategy is effectively applicable for the internet cafe to remain popular among people in Yogyakarta nowadays.

\section{Research Methods}

To do this research, the authors employed qualitative description methods from several paths to gather the data: observations, qualitative in-depth interviews (Pickering 2008) with managers, and qualitative in-depth interviews with consumers for supporting the analysis. For observations, a participatory observation was done in several internet cafes in Indonesia. We conducted this observation by becoming one of the consumers from January to September 2019. Data obtained from participant observations in the field were the overall technology offered, visitor activity, documentation, facilities, infrastructure, and the service system. Around 39 internet cafes around some big cities in Indonesia were selected by using purposive sampling. The samples were based on mapping internet cafes in some cities in Indonesia using Google maps by considering the review, popularity, and facilities provided. Those cities are West Java (Jakarta (8), Bogor (3)), Central Java (Semarang (4)), Bali (Denpasar (8)), East Java (Surabaya (2), Malang (2)), and Yogyakarta (12).

From those observations, we had found several criteria that finally made us decide as to why we chose Yogyakarta as a research location. Most internet cafes that we have visited (outside of Yogyakarta) have outlines of similar settings. Those are:

- internet cafe that provides a fast connection

- only focus on providing computers for online gaming purposes and supported by manufacturing company (such as Nvidia, Digital alliance, Team, etc.)

- computers supported by graphic cards and high processors to support online gaming or ESport (electronic sport).

- provision of hourly play package system based on computer specifications, the comfort of the chair, keyboard, mouse, and headphones.

- on the walls are usually displayed a background or poster of characters of a particular game.

We argue that the physical settings and atmosphere built for such internet design can be said to be more biased to an inevitable masculine dominance. Several studies support this finding that this kind of internet cafe provides facilities for male users in playing online games, such as Beavis and Charles (2007); Binark et al. (2009); Kristiansen et al. (2003); Laegran (2009); Liu (2009).

Based on the findings above, we find that the physical settings of the internet cafe in Yogyakarta are very different. We argue that most of the internet cafes in Yogyakarta are not like some cities in Indonesia which focus on creating an image of internet cafe for playing online games. Thus, this kind of internet cafe highlights online activities, where users need a high specs computer for being able to run certain online games. In contrast to this, an interesting finding of internet cafes in Yogyakarta is that consumers do not visit this place to use internet connections. Some of their online activities can be said only used to support offline practices. They create different needs for consumers when visiting an internet cafe.

Therefore, this research is limited to examine research objects on internet cafes in Yogyakarta. As we exposed earlier, we have found that internet cafes in Yogyakarta can be categorized into two chains of a branded segment of internet cafe. That list can be found in Table 1. Thus, we investigate these two chains as a case study. We present this case study, not in the realm of generally representing internet cafes in Indonesia, but it is intended to investigate what their effective strategies. Generally, these chains have the same physical settings, but they indirectly provide a variety options to consumers.

For this case, the novelty of the research method presented in this paper is this research applied the interdisciplinary approach to examine the sustainable strategy of internet cafe. This dynamical approach helped us 


\section{ENTREPRENEURSHIP AND SUSTAINABILITY ISSUES}

ISSN 2345-0282 (online) http://jssidoi.org/jesi/ 2020 Volume 8 Number 1 (September) http://doi.org/10.9770/jesi.2020.8.1(75)

to identify key factors in investigating why internet cafe thrives in mids of mobile technology. We consider the shifting of brand purpose and consumers' perception as elements of the study, including the physical settings. The data are supported by in depth-interview with consumers to qualitatively assess the application of the strategies adopted by managers as regulators of the business. We also applied random sampling for choosing the informants as the customers of these groups. The list of informants can be found in Table 2. In fact, to date, no research applies this method to study an internet cafe. Then, qualitative analysis helps to identify effective strategies implemented by an internet cafe to challenge the ubiquitous mobile technology nowadays.

\section{Results}

In this section, we present two chains of internet cafe which representing internet cafe in Yogyakarta. We do not pretend to distinguish these chains. Both represented the historical background of the existence of warnet and transformed into an internet cafe.

Based on interviews with manager group A, the embryo of the internet cafe in Yogyakarta started from its branch center, namely warnet A1 in 1996. In the following year, warnet A1 converted to apply the internet cafe concept by providing other facilities compared to an internet cafe in general, for instance, the availability of multimedia content (such as movies, mp3, antivirus, and softwares) and the existence of small spot for selling snacks and beverages.

Starting in 2000, group A built six branches that are spread out in almost bustling centers in Yogyakarta. In Indarti's (2004) research about internet cafe, the location of internet cafes that are close to schools, universities, or security forces has a positive impact on the internet cafe business. One reason is that they target students as a potential or niche market. Followed by group B, they built their first internet cafe in 2006 based on the crowded precedent of group A in the Northern area of Yogyakarta, because group A in that year only focused on the South area. Table 1 shows the branch list of internet cafe business chains in Yogyakarta. Group A has seven branches and $\mathrm{B}$ has four branches.

As producers, these chains create a new need or we call it as a gigabyte need (Wibowo, et al., 2020). This need covers digital contents, such as antivirus, MP3 songs or video clips, movies, series, TV shows, software, games, various e-books, and comics. They have their own team to always update these digital contents. The availability of that contents is free access for consumers. Furthermore, the added value of an internet cafe is a concept that combines places that provide internet access and cafe atmosphere. Physically, the internet cafe building is also built more modern to provide convenience for costumers. Thus, it answers the question of why warnet transforms into internet cafes, which is to keep costumers coming back as loyal consumers facilitated by several features and considering space as the expansion of consumption patterns.

Table 1. Internet cafe business chains and branches

\begin{tabular}{|c|c|c|c|}
\hline Group A & Established in (Year) & Group B & Established in (Year) \\
\hline A1 & 1996 & B1 & 2006 \\
\hline A2 & 2000 & B2 & 2009 \\
\hline A3 & 2007 & B3 & 2010 \\
\hline A4 & 2009 & B4 & 2016 \\
\hline A5 & 2009 & & \\
\hline A6 & 2010 & & \\
\hline A7 & 2013 & & \\
\hline
\end{tabular}

Source: Authors 


\section{ENTREPRENEURSHIP AND SUSTAINABILITY ISSUES}

ISSN 2345-0282 (online) http://jssidoi.org/jesi/ 2020 Volume 8 Number 1 (September) http://doi.org/10.9770/jesi.2020.8.1(75)

Both groups A and B have the same concept in creating the image of the internet cafe. They have the same format as well, namely the cubicle room and free space. A cubicle room is a space that provides a computer surrounded by booths or walls, while free space is a space designed for consumers who only want to enjoy the cafe's atmosphere as a modern hangout, high-speed wifi connection, comfortable sofa and work desks, and music in the background. This free space does not exist in a warnet, but it comes from the adoption of physical settings of internet cafes outside Indonesia.

Last, for supporting the data, the authors argue that consumers' perception will illustrate the success strategy of the internet cafe to thrive. The in depth-interview with informants will help the authors to understand deeper the position of internet cafe in consumers' life. Nevertheless, the authors believe that the data in Table 2 are dependent on the geographical location of each branch. But for internet cafes that have a business chain have predetermined standards (Chawla \& Behl, 2006). In other words, there is no standard difference in facilities and experience offered by all branches. That is why, this research only focuses on the micro case study of the sustainable strategy of internet cafe which supported by consumers' perception.

Table 2. Profile of subject

\begin{tabular}{|c|c|c|c|c|}
\hline Number & $\begin{array}{c}\text { Code of } \\
\text { subject }\end{array}$ & Education & Perception & $\begin{array}{l}\text { Use of Internet } \\
\text { cafe (Group) }\end{array}$ \\
\hline 1 & $\mathrm{~A}$ & Post-graduate & $\begin{array}{l}\text { I think that I was more comfortable coming to the internet cafe and } \\
\text { lazy to come back to the era of warnet. I think that internet cafes can } \\
\text { offer thousands of digital contents (Korean and Hollywood movies } \\
\text { and series) that can be accessed for free. }\end{array}$ & A, B \\
\hline 2 & B & Post-graduate & $\begin{array}{l}\text { Internet cafe is a cool place to update references for my job as an } \\
\text { illustrator, because it provides animations that are difficult to be } \\
\text { searched on the internet, such as silent animation and animation from } \\
\text { France. I can also copy a variety of movies as entertainment in my } \\
\text { boarding house. }\end{array}$ & A, B \\
\hline 3 & $\mathrm{C}$ & Post-graduate & $\begin{array}{l}\text { Internet cafe provides access to movies that I cannot watch in cinema } \\
\text { or movies that I want to watch again. In addition, I can to copy } \\
\text { various movies and serials. }\end{array}$ & B \\
\hline 4 & $\mathrm{D}$ & Post-graduate & $\begin{array}{l}\text { Internet cafe became a shortcut to access American serials. We do } \\
\text { not need to download it, but just copy it on our hard drive. }\end{array}$ & A \\
\hline 5 & $E$ & Undergraduate & $\begin{array}{l}\text { Internet cafe is a place like one-stop entertainment for unlimited } \\
\text { access to various movies, especially box office movies and local } \\
\text { movies. }\end{array}$ & A, B \\
\hline 6 & $\mathrm{~F}$ & Post-graduate & $\begin{array}{l}\text { Internet cafe provides a modern and aesthetic place to hangout with } \\
\text { my heartthrob to watch movies. In addition, I can access movies } \\
\text { immediately without wasting my time to wait. }\end{array}$ & $\mathrm{B}$ \\
\hline 7 & $\bar{G}$ & Undergraduate & $\begin{array}{l}\text { Internet cafe has become a place that always leads to a nostalgia for } \\
\text { accessing movies for free. I often go to there to copy movies and } \\
\text { animation for my niece at home for family time. }\end{array}$ & $\mathrm{B}$ \\
\hline 8 & $\mathrm{H}$ & Undergraduate & $\begin{array}{l}\text { Internet cafe is a paradise for people to copy all Korean series. It is a } \\
\text { comfortable place for the community to update Korean serials. }\end{array}$ & B \\
\hline 9 & I & Undergraduate & $\begin{array}{l}\text { Internet cafe provides game and software installers. I can install them } \\
\text { on a computer at home. I do not have to wait long time and spend my } \\
\text { quota when accessing them. }\end{array}$ & $\bar{A}$ \\
\hline 10 & $\mathrm{~J}$ & Undergraduate & $\begin{array}{l}\text { After work, I usually go to internet cafe. I can copy the title of } \\
\text { several movies in there for entertainment in the boarding house. }\end{array}$ & $\bar{A}$ \\
\hline
\end{tabular}

Source: Authors

Table 2 shows a summary of the general perception of all informants. According to John Urry (1995), a place is culturally constructed. Implicitly, the internet cafe is not a neutral place (p.2). An internet cafe business chain has been able to circulate images of internet experience as standardized and transferable, because the chain gives 


\section{ENTREPRENEURSHIP AND SUSTAINABILITY ISSUES}

ISSN 2345-0282 (online) http://jssidoi.org/jesi/ 2020 Volume 8 Number 1 (September) http://doi.org/10.9770/jesi.2020.8.1(75)

economic and cultural impact on internet public access (Wakeford, 2003). Internet cafe as a place is constructed and designed to attract customers, not only to access the internet, but also the space provided and the availability of cafe, including air-conditioned rooms, two stereo headphones, 24-inch LCD monitors, full music, sofa for two users, and the existence of prayer room, this space makes easy for some customers to worship. The existence of space that provides comfort makes customers feel at home to spend more time here.

In the addition to "consume" space, customers also consume the digital contents provided in their database for free. The space and digital contents have obscured customers with high prices that have become 'reasonable' for a one-hour access bill there. For an instance, a one-hour access bill in an internet cafe is 7500 IDR or 0.54\$ (2018), very different from warnet which is only around 3000 IDR or $0.21 \$$. Thus, this description is parallel with the customers' perception. It can be argued that there is a more detailed consumption practice in an internet cafe, namely the consumption of space and digital content.

\section{Discussion}

We begin the analysis of the results considering the transformation from warnet to internet cafe. Both groups provide a new level of consumption practice. First, the synthesis of previous studies in Table 3 illustrates that the internet cafe's space becomes a consumption site for customers. Several indicated words such as 'physical design', 'the existence of cafe', 'translocal images', 'domestic equivalent', and 'social space' contribute to the understanding that space has an important role to be on of the important elements of internet cafe. Therefore, we provide synthesis metadata or a critical interpretive synthesis of literature (Dixon-Woods et al. 2006; Wang et al., 2018) from previous studies about internet cafes around the world. This result can be seen in table 3.

Table 3. The previous internet cafe research

\begin{tabular}{|c|c|c|}
\hline Author & Context & Theme Contribution \\
\hline Lee (1999) & $\begin{array}{l}\text { South East } \\
\text { England }\end{array}$ & $\begin{array}{l}\text { - Internet cafe provides internet access in public spaces that are almost the same as the } \\
\text { domestic equivalent or home. } \\
\text { - Internet cafes become a social place and a place to provide a public identity with } \\
\text { fashionable and hyped technology. }\end{array}$ \\
\hline Wakeford (2003) & $\begin{array}{l}\text { England, } \\
\text { London }\end{array}$ & $\begin{array}{l}\text { - Internet cafe in a business chain provides a fundamental impact on the } \\
\text { standardization of experience offered. } \\
\text { - Internet cafe emphasizes the importance of physical design, making allies with fast } \\
\text { food outlets for their cafe and advertised on their related brands on-screen. } \\
\text { - There is less privacy when customers use a computer because the computer screen is } \\
\text { visible for others. }\end{array}$ \\
\hline $\begin{array}{c}\text { Lægran \& Stewart } \\
\text { (2003) }\end{array}$ & $\begin{array}{l}\text { Scotland and } \\
\text { Norway }\end{array}$ & $\begin{array}{l}\text { - There are a translocal images to offer a variety of internet cafe usage based on } \\
\text { different interests, such as trendy, healthy, and nerdy. } \\
\text { - Each of the internet cafes has its own criteria offered, for example, internet cafes for } \\
\text { socialization with healthy food (healthy), game center (nerdy), or trendy interior / } \\
\text { modern look (trendy). }\end{array}$ \\
\hline $\begin{array}{l}\text { Hyde-Clarke } \\
\text { (2006) }\end{array}$ & $\begin{array}{l}\text { South Africa, } \\
\text { Johannesburg }\end{array}$ & $\begin{array}{l}\text { - Internet cafe becomes a destination for people with lower income to improve local } \\
\text { skills and knowledge of the benefits of ICTs used. } \\
\text { - Internet cafes are dominated by male customers, where the main goal is to search for } \\
\text { female companionship. }\end{array}$ \\
\hline Räisänen (2006) & $\begin{array}{l}\text { China, } \\
\text { Shanghai }\end{array}$ & $\begin{array}{l}\text { - Internet cafe has an image to be a center for certain uses, such as suburban gaming } \\
\text { center, entertainment center, or cool time killer for spending time } \\
\text { - Internet cafe emphasizes more on the orientation to entertainment, gaming, and } \\
\text { socializing. } \\
\text { - In engagements with a foreign culture, customers are almost youth. There is a process } \\
\text { of negotiating identities, such as trendy and modern urbanities. }\end{array}$ \\
\hline Laegran (2008) & Norway & $\begin{array}{l}\text { - Internet cafe offers an urban atmosphere for playing games and as a social space. } \\
\text { - There is a separated space but still in one room. They separate the cafe and a game }\end{array}$ \\
\hline
\end{tabular}


ENTREPRENEURSHIP AND SUSTAINABILITY ISSUES

ISSN 2345-0282 (online) http://jssidoi.org/jesi/ 2020 Volume 8 Number 1 (September) http://doi.org/10.9770/jesi.2020.8.1(75)

\begin{tabular}{|c|c|c|}
\hline & & corner in the corner which is separated by a wall \\
\hline $\begin{array}{c}\text { Binark et al. } \\
(2009)\end{array}$ & $\begin{array}{c}\text { Turkey, } \\
\text { Ankara }\end{array}$ & $\begin{array}{l}\text { - Internet cafes offer several popular games and customers can sometimes earn money } \\
\text { from the game. } \\
\text { - Customers use internet cafe as a place to socialize offline and online. }\end{array}$ \\
\hline $\begin{array}{c}\text { LeBlanc \& Shrum } \\
(2017)\end{array}$ & Ghana, Accra & $\begin{array}{l}\text { Internet cafe as public internet access is not affected by the diffusion of mobile } \\
\text { devices. } \\
\text { - Internet cafes are not in a period of growth, but rather adapt to the added values of } \\
\text { traditional business, such as making a game center or conference call center. }\end{array}$ \\
\hline
\end{tabular}

Source: Authors

From Table 3, in particular, the identification of the material and physical setting of internet cafe is based on the internet connection, the existence of the cafe, and the computer itself. Table 3 has highlighted that the center of consumption in an internet cafe and the existence of cafe rely on local consumption and virtual consumption which refers to global consumption that made possible through an internet connection, for example, online activities such as checking email, online shopping, online transactions, searching information, and playing online games. Here we report the discovery that can be said to be different from previous studies related to image formation introduced by internet cafes in Yogyakarta.

As stated by manager group A dan B, they affirmed that the existence of the cafe is intended to provide flexible access for consumers, especially in the current era, consumers prefer to come to bring their laptop and require high-speed wifi access. Internet cafe has free space to provide comfort such as work in a group or working space, doing assignments, social place, meeting, and spending time to play a game using a smartphone, because the majority of customers are targetted towards university students. As the manager A said, the cafe (free space) was originally only a complement of cubical rooms and may only have a 30\% market, but now (2018) it has reached $60 \%$ and $40 \%$ for cubical rooms.

Next, in cubical rooms, we found different activities with the past results from previous studies, namely the internet cafe as a place to socialize offline and online. In our case, the authors did not find that relationship between offline and online or playing online games on a computer, but customers merely focus on the screen to access digital contents. All internet cafes provide digital contents on the local server, host-to-host. It needs to be understood in the context of the practice of copying digital content; consumers duplicate (copy and paste) digital content from the local server or databases to consumers' devices (hard disk). Some categories of digital contents stored in databases are various, such as antivirus, mp3 or video clip songs, movies, drama series and TV shows, software, games, e-books, and comics. This condition suggests the fact that the internet connection in internet cafe is not merely essential or as complement because consumers use the internet are only used to support offline activities. The internet is only used to search movie references in Google Search. The customers only prefer to check email, chatting, and play online games through their smartphone or laptop. This fact can be indicated that the hard disk becomes an important property for customers when visiting internet cafe. Most of the new generation tends to access entertainment, especially watching movies. They prefer to stream and download movies (Tirto 2017). We should refer to 'Popcorn Time', whereby consumers are faced with an easy, free, and simple to access millions of digital contents on a torrent (peer-to-peer file sharing access), pirated television shows, and movie files that are freely accessible to streaming with a variety of subtitles through consumer-owned screens (Strangelove 2015). In this paper, digital content is the key factor where computers in internet cafes are still popularly accessed by consumers. They create a giga byte need.

In that case, there is a commodification process. Commodification is a transforming process from use-values for marketable products into exchange-values (Mosco 2019). The practice in copying digital files has implications that something new can be explored. If previous studies mention that the billing is based on online activities, the 


\section{ENTREPRENEURSHIP AND SUSTAINABILITY ISSUES}

ISSN 2345-0282 (online) http://jssidoi.org/jesi/

2020 Volume 8 Number 1 (September)

http://doi.org/10.9770/jesi.2020.8.1(75)

billing precisely will be forged in the activity of copying digital content from the local server to customers' harddisk. Digital contents that are provided free of charge give an impact on the length of time computer access.

Local Narrative to Incrase Customers Engagement: Adopting Global Strategy

Compared with cafes in general (e.g. Starbucks), all managers said that to differentiate from a cafe, they provide foods and beverages that are almost the same as the menu at the cafe but with cheaper price supported with a faster wifi connection. This narration leads to different context with the study from Venkatraman \& Nelson (2008) and Grinshpun (2018), they explore the transformation of consumption patterns in Starbucks from servicescape to consumptionscape. Yet, this kind of cafe emphasizes the physical designs to provide material for consumptionscape created by consumers for private experience. If Starbucks is a part of the role of global chains that is adapted to local culture (glocalization), in this research, we argue that internet cafe in Yogyakarta has adopted the distinctive global characters and domesticated to build a new local brand.

Brand image engages the consumer audience to give their trust to buy a product or service. Thus, a brand succeeds to give a meaningful experience that will determine the loyalty of consumers and give share values from their experiences (Wijaya, 2013). Today, a great product is not enough to attract consumers to buy (Kapferer 2008; Wijaya et al. 2016). A brand has to apply development strategy by maximizing resources to support business development in adding value to entrepreneurship (Wijaya 2013; Wijaya et al. 2016). A brand is a tool that is integrated with the product or service offered. A brand is also a differentiate tools through values (tangible and intangible) (Kapferer 2008).

In this context, the two internet cafe business chains try to create a strong brand in the local area. They created line product categories with the concept of internet cafe as a place for hangout, co-working space, high-speed wifi connection, and access to almost all digital contents provided free of charge. However, groups A and B have different goals in determining niche markets. Group A offers more values to focus more on developing the concept of an internet cafe as an internet learning cafe that seeks to adapt university students' inclination to use this space as a learning space. While group B emphasizes access to watch more premium movies and serials, which presents Netflix video streaming without additional subscriptions or payment when accessing a computer.

However, the difference in the target market helps groups A and B distinguish themselves. In addition, they adopted the global strategy of the internet cafe business chain to be adapted and applied locally. The effectiveness of this strategy gives an impact on customers. It can be seen in Figure 1; we try to give an illustration about consumers' perception toward the difference between warnet and internet cafe. Customers have a positive perception when they visit internet cafe and tend to avoid visiting warnet. They prefer to visit one place that can provide coziness and flexibility to do various activities. The authors agree with (LeBlanc \& Shrum 2017) that internet cafe business in the current era is not in the realm of growth, but adaptation. They adapt to the development of mobile technology and changes in consumers' behavior. 


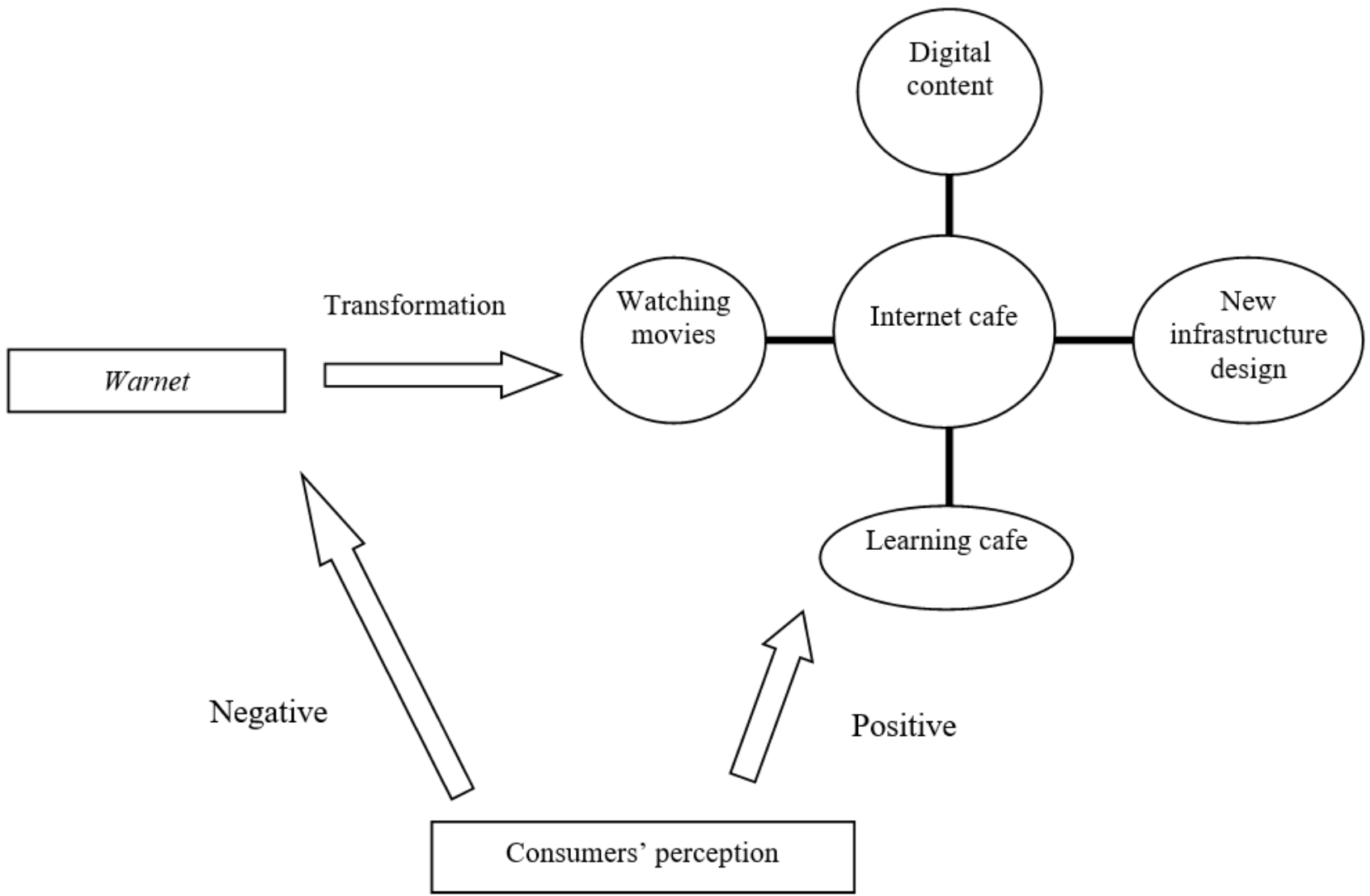

Figure 1. Reconstruction of the design of internet cafe Source: developed by the authors

(based on interview data with managers and informants)

The purpose behind theming is for marketing purposes and businesses to increase sales, add value, and sell at a high price. This theming strategy tries to create a memorable experience and unique experiential value, to differentiate the services offered to consumers, and to compete in an increasingly crowded market (Åstrøm 2019). In other words, what is being sold now in internet cafe is not only services that are provided, but also but also as a place where consumers are able to create meaningful experiences when visiting internet cafe.

The development of internet cafes in Yogyakarta has survived by adopting the global strategy of physical settings of internet cafe, in terms of infrastructure and facilities and domesticated to local culture and target market. This condition gives the flexibilities for consumers to create his/her meaningful experience. A key to understanding internet cafes in this paper is that internet cafes in a particular city can thrive and be popular, because they construct new consumption sites that are standardized through their branches. Thus, they can maximize not only the business revenue through their value, but also cultural impact on the internet public access in that city.

\section{Conclusions}

This research shows that sustainable strategies employed by internet cafes in Yogyakarta are successful in building a strong local brand. It has been proven to raise an effective impact on customers who have a positive perception to gauge the benefits of internet cafes. Customers also have an awareness that they visit internet cafe 


\section{ENTREPRENEURSHIP AND SUSTAINABILITY ISSUES}

ISSN 2345-0282 (online) http://jssidoi.org/jesi/ 2020 Volume 8 Number 1 (September) http://doi.org/10.9770/jesi.2020.8.1(75)

for hangout, doing assignments, meeting, or copying digital contents. In conclusion, internet cafe in this research is not in the realm of growth but adaptation. In line with the sustainable strategy implemented by both internet cafe business chains in Yogyakarta, they adopted the role of global strategies to develop in terms of infrastructure, cafe ambience, design, translocal images and facilities. In addition, internet cafes also create the expansion of consumption patterns through the presence of digital content provided on their local servers. It is parallel with customers' behavior as a young generation that has easy access and feature-rich interface to access digital contents (movies) and serials through their mobile-screen. Therefore, to be able to thrive and to remain popular in nowdays, the intersection between global strategy, standardization, and adaptation is an effective strategy to increase the sustainability development of internet cafe.

\section{References}

Åstrøm, J. K. (2019). Why Theming ? Identifying The Purposes Of Theming In Tourism. Journal of Quality Assurance in Hospitality \& Tourism, O(0):1-22. DOI: 10.1080/1528008X.2019.1658147

Beavis, C., \& Charles, C. (2007). Would The "real" Girl Gamer Please Stand Up? Gender, LAN Cafés And The Reformulation Of The "Girl" Gamer. Gender and Education, 19(6):691-705. DOI: 10.1080/09540250701650615

Binark, M., Sütcü, G. B., \& Buçakçı, F. (2009). How Turkish Young People Utilize Internet Cafes: The Results Of Ethnographic Research In Ankara. Observatorio (OBS*) Journal, 3(1):286-310. DOI: 10.15847/obsOBS312009249

Chawla, D., \& Behl, R. (2006). Perception Study Of Cyber Café Users. Global Business Review, 7(1):17-41. DOI: $10.1177 / 097215090500700102$

Dixon-Woods, D., Agarwal, S., Annandale, E., Arthur, A., Harvey, J., \& Riley, R. (2006). Conducting A Critical Interpretive Synthesis Of The Literature On Access To Healthcare By Vulnerable Groups. BMC Medical Research Methodology, 6(1):35-47. DOI: 10.1186/1471-2288-6-35

Grinshpun, H. (2018). International Research Centre for Japanese Studies, National Institute for the Humanities The City and the Chain: Conceptualizing Globalization and Consumption in Japan Author (s): Helena Grinshpun Source : Japan Review , No . 24 ( 2012 ), pp. 169-19. 24(24):169-195.

Hanley, J. (2002). Women, Art, And Technology: A Brief History. In D. B. Fuller \& D. Salvioni (Eds.), Art, women, California 1950-2000 (pp. 311-319). Berkeley: University of California Press.

Hill, D. T., \& Sen, K. (1997). Wiring The Warung To Global Gateways: The Internet In Indonesia. Indonesia, 63:67-69. DOI: $10.2307 / 3351511$

Hill, D. T., \& Sen, K. (2005). The Internet in Indonesia's New Democracy. New York: Routledge.

Hyde-Clarke, N. (2006). The Urban Digital Divide: A Comparative Analysis Of Internet Cafés In Johannesburg, South Africa. Review of African Political Economy, 33(107):150-156. Retrieved from https://www.jstor.org/stable/4007119

Indarti, N. (2004). Business Location And Success: The Case Of Internet Café Business In Indonesia. Gadjah Mada International Journal of Business, 6(2):171. DOI: 10.22146/gamaijb.5543

Kapferer, J. N. (2008). The new strategic brand management: Creating and sustaining brand equity long term. London: Kogan Page.

Karina, S. (2011). Warnet Di Indonesia Mulai Kehilangan Pengunjung. Retrieved November 15, 2016, from Okezone.com website: http://techno.okezone.com/read/2011/11/15/55/529807/warnet-di-indonesia-mulai-kehilangan-pengunjung

Kristiansen, S., Furuholt, B., Wahid, F., \& Bjørn, hiano. (2003). Internet café entrepreneurs Pioneers in information dissemination in Indonesia.

Laegran, A. S. (2009). Technosocial Space: Connecting People And Places. In P. Turner, S. Turner, \& E. Davenport (Eds.), Exploration of Space, Technology, and Spatiality: Interdisciplinary Perspectives (pp. 54-69). DOI: 10.4018/978-1-60566-984-7.ch072

Laegran, A. S., \& Stewart, J. (2003). Nerdy, Trendy Or Healthy? Configuring The Internet Café. New Media and Society, 5(3):357-377. DOI: $10.1177 / 14614448030053004$

LeBlanc, M., \& Shrum, W. (2017). The Evolution Of Ghanaian Internet Cafés, 2003-2014. Information Technology for Development, 23(1):86-106. DOI: 10.1080/02681102.2016.1263594

Lee, S. (1999). Private Uses In Public: A Study Of An Internet Cafe. New Media \& Society, 1(3):331-350. DOI: $10.1177 / 14614449922225618$

Liff, S., \& Laegran, A. S. (2003). Cybercafes: Debating The Meaning And Significance Of Internet Access In A Cafe Environment. New Media \& Society, 5(3):307-312. DOI: 10.1177/14614448030053001

Lim, M. (2003a). From War-Net To Net-War: The Internet And Resistance Identities In Indonesia? International Information and Library Review, 35(2-4):233-248. DOI: 10.1080/10572317.2003.10762603

Lim, M. (2003b). The Internet, Social Networks, And Reform In Indonesia. In N. C. and J. Curran (Ed.), Contesting Media Power: Alternative Media in a Networked World (pp. 273-288). Lanham, MD: Rowman \& Littlefield Publishers, Inc.

Liu, F. (2009). It Is Not Merely About Life On The Screen: Urban Chinese Youth And The Internet Café. Journal of Youth Studies, 12(2):167-184. DOI: 10.1080/13676260802590386

López-Bonilla, G., Yáñez-Kernke, M. del C., \& Vidauri-González, G. (2016). Cybercafés As Constellations Of Social Practices: Exploring 


\section{ENTREPRENEURSHIP AND SUSTAINABILITY ISSUES}

ISSN 2345-0282 (online) http://jssidoi.org/jesi/ 2020 Volume 8 Number 1 (September) http://doi.org/10.9770/jesi.2020.8.1(75)

"Place” And “Technospace” In Cybercafés In México. Cogent Social Science, 2(1):1-15. DOI: 10.1080/23311886.2016.1254846 Mancebo. (2003). Cybercafes. In K. Christensen \& D. Levinson (Eds.), Encyclopedia of community: From the village to the virtual world (pp. 368-370). Thousand Oaks: Sage.

Mosco, V. (2009). The Political Economy of Communication (2nd ed.). London: SAGE Publications Ltd.

Mutula, S. M. (2003). Cyber Cafe Industry In Africa. Journal of Information Science, 29(6):489-497. DOI: 10.1177/0165551503296006

Pickering, M. (Ed.). (2008). Research methods for cultural studies. Edinburgh: Edinburgh University Press Ltd.

Räisänen, P. (2006). The urban technospace: a study on internet cafés in Shanghai. Retrieved from https://lup.lub.lu.se/studentpapers/search/publication/1327545

Strangelove, M. (2015). POST-TV Piracy, Cord-Cutting, and the Future of Television. Toronto: University of Toronto Press.

Tirto. (2017). Tirto Visual Report Masa Depan Di Tangan Generasi Z. Retrieved March 5, 2018, from https://tirto.id/tirto-visual-reportmasa-depan-di-tangan-generasi-z-ctMM

Urry, J. (1995). Consuming places. London: Routledge.

Venkatraman, M., \& Nelson, T. (2008). From Servicescape To Consumptionscape: A Photo-Elicitation Study Of Starbucks In The New China. Journal of International Business Studies, 39(6):1010-1026. DOI: 10.1057/palgrave.jibs.8400353

Wakeford, N. (2003). The Embedding Of Local Culture In Global Communication: Independent Internet Cafés In London. New Media and Society, 5(3):379-399. DOI: 10.1177/14614448030053005

Wibowo, T. O., Udasmoro, W., \& Noviani, R. (2020). Understanding New Consumption Sites Of Internet Cafe In Yogyakarta, Indonesia. Jurnal Ilmu Sosial Dan Ilmu Politik, 23(3):237. DOI: 10.22146/jsp.51707

Wang, Y., Deng, Q., \& Ji, S. (2019). Understanding Café Culture: Toward A Dynamic And Holistic Research Framework. Journal of Global Marketing, 32(1):37-48. DOI: 10.1080/08911762.2017.1420838

Wijaya, B. S. (2013). Dimensions Of Brand Image: A Conceptual Review From The Perspective Of Brand Communication. European Journal of Business and Management, 5(31):55-65. DOI: 10.13140/ejbm.2013.55.65

Wijaya, B. S., Suharyanti, Hanathasia, M., \& Kania, D. (2016). Synergizing Entrepreneurial Spirit And The Mindset Of Branding Through Branderpreneurship: Evidences From Indonesia. Social Sciences (Pakistan), Vol. 11, pp. 129-138. DOI:

10.3923/sscience.2016.129.138

\section{Acknowledgements}

This paper is a part of the project entitled 'Consumption Practices of Internet Cafe Users in Yogyakarta', which is funded by Indonesia Endowment Fund for Education (LPDP).

Tangguh Okta WIBOWO is a doctoral student in Media and Cultural Studies, the Graduate School of Universitas Gadjah Mada, Indonesia. Research interests: cyberculture, critical studies in advertising, marketing, freedom of speech in social media, and new media.

ORCID ID: orcid.org/0000-0002-2619-6561

Wening UDASMORO is Associate Professor of Literature in Universitas Gadjah Mada (UGM), Indonesia. She received her PhD in Gender Studies from the University of Geneva, Switzerland in 2005. Currently, she is the Dean of the Faculty of Cultural Sciences, UGM. Research interests: critical discourse analysis, gender, literature, and identity politics.

ORCID ID: https://orcid.org/0000-0002-6166-608X

Ratna NOVIANI is a Lecturer at Media and Cultural Studies, the Graduate School, Universitas Gadjah Mada. She obtained her PhD from Department of Media Studies, Ruhr Universität Bochum, Germany in 2009. Research interests: media and politics of representation, gender and media, youtuh culture, and advertising and consumer culture.

ORCID ID: orcid.org/0000-0003-4699-9297

Make your research more visible, join the Twitter account of ENTREPRENEURSHIP AND SUSTAINABILITY ISSUES: @Entrepr69728810

Copyright (C) 2020 by author(s) and VsI Entrepreneurship and Sustainability Center

This work is licensed under the Creative Commons Attribution International License (CC BY).

http://creativecommons.org/licenses/by/4.0/

(c) (i) Open Access 